\title{
Effect of Organic Manure and in-organic Fertilizer on Growth, Yield and Quality of Bitter Gourd [Momordica charantia L.]
}

\author{
Ch. Prashanthi*, Deepanshu and Reshma \\ Department of Horticulture, Naini Agricultural Institute, Sam Higginbottom University of \\ Agriculture, Technology and Sciences, Prayagraj-211007, India \\ *Corresponding author
}

\section{A B S T R A C T}

The present experiment was carried out during July to October 2019 in Research Field, Department of Horticulture, SHUATS, Prayagraj. The experiment was

Keywords

Bitter gourd, RBD, NPK, Poultry manure,

Vermicompost, FYM

Article Info

\section{Accepted:}

15 January 2021

Available Online:

10 February 2021 conducted in Randomized Block Design (RBD), with 13 treatments, replicated thrice with Organic (FYM, Vermicompost, Poultry manure \& inorganic (NPK) on growth, yield and quality of Bitter Gourd.The application of effect of inorganic fertilizer $50 \% \mathrm{NPK}$ and organic $50 \%$ vermicompost, $50 \%$ poultry manure was found to be best treatment combination for yield and yield attributing traits and as well as for benefit cost ratios and had a beneficial effect on bitter gourd. The maximum average yield (55.84), Fruit yield per plant (kg) (2.79) average fruit width (16.05) average fruit weight $\mathrm{g}$ (58.59) average fruit length $\mathrm{cm}$ (13.88) first female flower (51.85), number of primary branch (3.64) (8.54) (14.78) and vine length (130.44) (250.47) (376.06) was recorded for 30,45,60 days.It was also observed that some of the quality attributes like TSS (o Brix), of the fruit were significantly influenced with the application of different levels of vermicompost while vitamin $\mathrm{C}$ were significantly affected with the application of both organic and inorganic fertilizers in different combinations.

\section{Introduction}

Bitter gourd (Momordica charantia L.) is atropical and subtropical vegetable crop of the family cucurbitaceae. Bitter gourd is a leading vegetable crop of India, the higher yield and maximum returns make it the most preferred vegetable crop of Indian farmers. Fruits are considered as a rich source of vitamins and minerals and are rich in vitamin $\mathrm{C}(88 \mathrm{mg} / 100$ g). It possesses antioxidant, antimicrobial, antiviral, antihepatotoxic, anti ulcerogenic properties and also has the ability to lower blood sugar (Behera, 2011). It has great demand in domestic and international market among fresh vegetables due to its hypoglycaemic property. Leading states growing the crop are Andhra Pradesh followed 
by Odisha, Bihar, Chhattisgarh and Madhya Pradesh. It is grown both in rainy season and as well in spring summer season. Fruits vary in shapes, size, colour and bitterness. Bitter gourd responds well to manure and fertilizer applications. However, continuous use of the heavy doses of fertilizers damage the natural ecology and adversely affects the nutrient recycling and the biological communities in soil which otherwise support the crop production (Prasad et al., 2009). Therefore, it is being increasingly realized that organic manure is the cheapest eco-friendly resource for providing nutrients to crop plant and helps in curtailing the use of chemical fertilizers. Manures not only supply plant nutrients but also add organic matter, which improve physical condition of soil (Lundwick and Johnston, 2002). At present agriculture is highly dependent on use of chemical fertilizers, pesticides for obtaining high yield. This dependence in associated with problems such as cost of cultivation, nutrient recycling and soil fertility. Thus the use of expensive commercial fertilizer as per the requirement of the crop not much affordable to the small and marginal farmers. So this is necessitates to use of organic manure and inorganic fertilizers for maintaining and sustaining high level of soil fertility and crop productivity.Therefore keeping the above points a research trial was evaluate to study the suitable doses of organic manure and inorganic fertilizers for growth, yield and quality of Bitter gourd and to work out the Economics of treatment of Bitter gourd.

\section{Materials and Methods}

The experiment was conducted at Central Research Farm, Department of Horticulture, Naini Agricultural Institute, Sam Higginbottom University of Agriculture, Technology \& Sciences, Prayagraj (UP) during 2018-2019. All the facilities necessary for cultivation, including labours were made available in the department. To study Effect of Organic Manure and In Organic Fertilizer on Growth, Yield and quality of Bitter gourd. Prayagraj is located in the South-East part of Uttar Pradesh, India. Prayagra falls under agro- climatic zone IV, which is named as "Middle Gangetic Plains".

The site of experiment is located at $25.57^{\circ} \mathrm{N}$ latitude, $81.51^{\mathrm{o}} \mathrm{E}$ longitude and 98 meter above the sea level. The temperature falls down as low as $4-5^{\circ} \mathrm{C}$ during winter.

The average rainfall in this area is around during winter season especially in the months of December and January. The average rainfall in this area is around $103.4 \mathrm{~mm}$ annually with maximum concentration during July to October with few showers and drizzles in winter also.

The soil of the experiment plot was sandy loam in texture, poor in Phosphorus and rich in potash. The $\mathrm{pH}$ of the soil is slightly towards alkalinity. The soil reaction was suitability for cultivation of bitter gourd.

The experiment was laid out in RBD Randomized block design with 13 treatments and each replicated thrice the treatments were $\left(\mathrm{T}_{0}\right)$ Control [RDF NPK (120:60:60)+ 20t FYM)], $\left(\mathrm{T}_{2}\right) 100 \%$ RDF NPK, $\left(\mathrm{T}_{3}\right) 100 \%$ RDF $\mathrm{NPK}+$ Vermicompost@ 10 t/ha, $\left(\mathrm{T}_{4}\right)$ 100\%RDF NPK + Poultry manure @ 5t/ha, $\left(\mathrm{T}_{5}\right) 100 \% \mathrm{RDF}$ of NPK + Vermicompost 5 t/ha +Poultry manure $2.5 \mathrm{t} / \mathrm{ha},\left(\mathrm{T}_{6)}\right) 75 \%$ RDF of $\mathrm{NPK}+25 \% \mathrm{FYM},\left(\mathrm{T}_{7}\right) 75 \% \mathrm{RDF}$ of NPK + $25 \%$ Vermicompost, $\left(\mathrm{T}_{8}\right) 75 \%$ RDF of NPK + $25 \%$ Poultry manure, $\left(\mathrm{T}_{9}\right) 75 \%$ RDF of NPK $+25 \%$ Vermicompost + Poultry manure, $\left(\mathrm{T}_{10}\right)$ $50 \%$ RDF of NPK $+50 \%$ FYM, $\mathrm{T}_{11} 50 \%$ RDF of NPK $+50 \%$ Vermicompost, $\left(\mathrm{T}_{11}\right) 50 \% \mathrm{RDF}$ of NPK $+50 \%$ Poultry manure, $\left(\mathrm{T}_{12}\right) 50 \%$ RDF of NPK $+50 \%$ Vermicompost + Poultry manure. Treatment wise FYM were applied before sowing of seeds and mixed with soil. 
The dose of nitrogen as urea with dose of phosphorus (P2O5) as DAP, potash (K2O) as murate of potash and vermicompost, poultry manure, FYM were applied before sowing of seeds as per pit, in commensuration with treatments specifications. The remaining two doses was applied in two split doses at an interval of Thirty and sixty days after sowing of seeds.

The observations recorded for the plants were worked out to give means in respect of growth, yield and quality parameters, which were utilized in statistical analysis by the method of analysis of the variance prescribed by (Fisher, 1950). Comparison of the treatments was made with the help of critical differences (CD).

\section{Results and Discussion}

The morphological characters of bitter gourd crop namely, length of main vine $(\mathrm{cm})$, number of branches per vine, days to first female and male flower emergence, taken to first fruit picking, number of fruit per plant,fruit length $(\mathrm{cm})$, fruit weight $(\mathrm{g})$, furit width, Average yield $\mathrm{t}$ ha-1, Day taken for germination were influenced by the combined application of Organic and In Organic 50\% NPK + 50\% Vermicompost + Poultry manure. Recommended dose NKP and FYM alone could not influence the ggermination or the yield character significantly as compared to combined application. The data pertaining to the various observations on growth parameters in bitter gourd have been show in Table 1 and that regarding yield and economics in Bitter gourd Table 2.

Application of $50 \%$ NPK $+50 \%$ vermicompost $+50 \%$ Poultry manure brought significantly increased length of main vine (376.06) and number of branches (14.78) per plant, number of fruits (47.66), Average fruit length $(13.88 \mathrm{~cm})$, Average fruit weight
$(58.59 \mathrm{~g})$, Average fruit width $(16.05 \mathrm{~cm})$ fruit yield (2.79kg) TSS (5.56) Vitamin C (5.15) and also the Average yield (55.84t). All the yield parameters and yield improved due to the application of higher dose of NPK + vermicompost + poultry manure because, vermicompost provided better nutrition status by improving the physical, biological and chemical properties of soil.NPK, FYM, vermicompost and poultry manure mixture portably stimulates the root growth through efficient translocation of growth promoting substances synthesized in plant followed by enhanced nutrients absorption. Rate of various physiological and biochemical processes enhanced due to development of large photosynthetic areas comprising of wider leaf area and higher weight of branch was observed.

At the same time the main aim of Organic and In Organic is to minimize the use of chemical fertilizers without sacrificing the yield.

Vermicomposts, Poultry manures, Farmyard manure (FYM) etc. are organic manures, although supply low quality of major nutrients, but have potential to supply all essential nutrients for longer periods.

The increase in growth parameters such as plant height and number of branches may be due to the application of organic manure, which facilitates quick and greater availability of plant nutrients and thus provides a better environment for root growth and proliferation.

It also creates more adsorptive surface for uptake of nutrients. Application of $75 \%$ NPK $+25 \%$ vermicompost+ poultry manure significantly decreased the days taken for vine,and first female flower appearance,male flowers days to first fruit picking and average length, width, weight was followed by $50 \%$ $\mathrm{NPK}+50 \%$ vermicompost + Poultry manure in all the cases. 
Table.1 Effect of organic manure and in organic fertilizer and its interactions on growth of bitter gourd

\begin{tabular}{|c|c|c|c|c|c|c|c|c|c|c|}
\hline \multirow[t]{2}{*}{ Treatments } & \multirow{2}{*}{$\begin{array}{l}\text { Days taken } \\
\text { for germin } \\
\text { ation }(\%)\end{array}$} & \multicolumn{3}{|c|}{ Vine length (cm) } & \multicolumn{3}{|c|}{$\begin{array}{l}\text { Number of primary } \\
\text { branches per plan }\end{array}$} & \multirow{2}{*}{$\begin{array}{l}\text { No. of day } \\
\text { to female } \\
\text { flower }\end{array}$} & \multirow{2}{*}{$\begin{array}{l}\text { No. of days } \\
\text { to male } \\
\text { flower }\end{array}$} & \multirow[t]{2}{*}{$\begin{array}{l}\text { No. of Fruit } \\
\text { per plant }\end{array}$} \\
\hline & & 30 DAS & 60 DAS & 90 DAS & 30 DAS & $\begin{array}{c}60 \\
\text { DAS }\end{array}$ & 90 DAS & & & \\
\hline $\mathbf{T}_{\mathbf{0}}$ & 14.56 & 102.29 & 201.80 & 288.14 & 1.15 & 3.97 & 7.30 & 40.81 & 44.85 & 29.14 \\
\hline $\mathbf{T}_{1}$ & 13.48 & 116.05 & 218.31 & 313.28 & 2.41 & 5.40 & 10.23 & 49.75 & 41.81 & 30.51 \\
\hline $\mathbf{T}_{2}$ & 11.33 & 110.41 & 233.95 & 327.73 & 2.44 & 5.36 & 11.59 & 46.24 & 43.19 & 35.47 \\
\hline $\mathbf{T}_{\mathbf{3}}$ & 12.58 & 112.08 & 229.23 & 332.26 & 2.52 & 6.51 & 10.65 & 42.34 & 36.79 & 37.20 \\
\hline $\mathbf{T}_{4}$ & 11.19 & 118.25 & 232.36 & 342.87 & 3.38 & 6.47 & 10.03 & 47.30 & 36.05 & 39.47 \\
\hline $\mathbf{T}_{5}$ & 13.34 & 120.72 & 228.44 & 338.17 & 2.88 & 5.44 & 10.92 & 46.30 & 33.02 & 34.17 \\
\hline $\mathbf{T}_{6}$ & 11.29 & 119.44 & 229.52 & 340.20 & 2.94 & 4.96 & 11.52 & 47.39 & 32.22 & 34.21 \\
\hline $\mathbf{T}_{7}$ & 12.68 & 115.66 & 231.58 & 342.61 & 2.61 & 5.51 & 10.70 & 42.04 & 31.74 & 31.84 \\
\hline $\mathbf{T}_{8}$ & 10.55 & 127.24 & 247.52 & 368.22 & 3.27 & 7.42 & 13.01 & 41.07 & 30.43 & 44.50 \\
\hline $\mathbf{T}_{9}$ & 12.59 & 120.15 & 234.00 & 361.92 & 2.92 & 6.64 & 10.42 & 42.31 & 34.10 & 33.52 \\
\hline $\mathbf{T}_{10}$ & 11.51 & 121.66 & 243.77 & 368.61 & 2.74 & 5.51 & 11.22 & 42.77 & 39.73 & 43.02 \\
\hline $\mathbf{T}_{11}$ & 13.38 & 118.95 & 239.70 & 355.83 & 2.52 & 5.70 & 12.30 & 48.97 & 31.87 & 40.50 \\
\hline $\mathbf{T}_{12}$ & 10.21 & 130.44 & 250.47 & 376.06 & 3.64 & 8.54 & 14.78 & 51.85 & 29.39 & 47.66 \\
\hline S.Ed. (+) & 0.138 & 1.793 & 2.070 & 3.301 & 0.225 & 0.378 & 0.824 & 1.623 & 0.898 & 1.676 \\
\hline C.D. at $0.5 \%$ & 0.286 & 3.701 & 4.271 & 6.814 & 0.465 & 0.779 & 0.399 & 3.349 & 1.853 & 3.458 \\
\hline F-Test & $\mathrm{S}$ & $\mathrm{S}$ & $\mathrm{S}$ & S & $\mathrm{S}$ & $\mathrm{S}$ & $\mathrm{S}$ & S & $\mathrm{s}$ & $\mathrm{S}$ \\
\hline CV & 1.384 & 1.862 & 1.091 & 1.180 & 10.134 & 7.76 & 4.394 & $4 . .385$ & 3.072 & 5.495 \\
\hline
\end{tabular}


Table.2 Effect of organic manure and in organic fertilizer and its interactions on yield, quality of bitter gourd

\begin{tabular}{|c|c|c|c|c|c|c|c|}
\hline Treatments & $\begin{array}{l}\text { Average fr } \\
\text { uit length } \\
(\mathrm{cm})\end{array}$ & $\begin{array}{l}\text { Average fruit } \\
\text { weight (g) }\end{array}$ & $\begin{array}{c}\text { Average } \\
\text { fruit width } \\
\text { (cm) }\end{array}$ & $\begin{array}{c}\text { Fruit yield } \\
\text { per plant }(\mathrm{kg})\end{array}$ & $\begin{array}{l}\text { Average yield } \\
\quad(t \text { ha-1) }\end{array}$ & $\begin{array}{c}\text { TSS } \\
\left({ }^{\mathbf{0}} \text { Brix }\right)\end{array}$ & $\begin{array}{c}\text { Vitamin } \\
\text { C(mg) }\end{array}$ \\
\hline $\mathbf{T}_{\mathbf{0}}$ & 7.27 & 32.14 & 7.04 & 0.93 & 18.67 & 2.92 & 3.25 \\
\hline $\mathbf{T}_{1}$ & 8.77 & 37.73 & 8.43 & 1.20 & 24.02 & 3.85 & 3.40 \\
\hline $\mathbf{T}_{2}$ & 9.18 & 38.20 & 10.07 & 1.35 & 27.00 & 4.01 & 4.28 \\
\hline $\mathbf{T}_{\mathbf{3}}$ & 11.56 & 41.50 & 12.09 & 1.55 & 30.90 & 3.96 & 4.00 \\
\hline $\mathbf{T}_{4}$ & 10.26 & 41.83 & 13.85 & 1.65 & 33.02 & 4.37 & 4.14 \\
\hline $\mathbf{T}_{5}$ & 12.23 & 40.93 & 13.56 & 1.40 & 27.93 & 4.34 & 4.55 \\
\hline $\mathbf{T}_{6}$ & 12.36 & 45.85 & 12.91 & 1.57 & 31.45 & 4.10 & 4.14 \\
\hline $\mathbf{T}_{7}$ & 12.44 & 39.62 & 13.28 & 1.77 & 35.31 & 4.74 & 4.20 \\
\hline $\mathbf{T}_{8}$ & 13.27 & 55.50 & 15.22 & 2.09 & 41.79 & 4.79 & 4.74 \\
\hline $\mathbf{T}_{9}$ & 10.59 & 44.87 & 12.61 & 1.69 & 30.09 & 3.86 & 4.07 \\
\hline $\mathbf{T}_{10}$ & 12.40 & 48.56 & 15.05 & 1.50 & 33.85 & 4.49 & 3.44 \\
\hline$T_{11}$ & 12.47 & 44.23 & 14.92 & 1.79 & 35.80 & 3.94 & 4.36 \\
\hline $\mathbf{T}_{12}$ & 13.88 & 58.59 & 16.05 & 2.79 & 55.84 & 5.56 & 5.15 \\
\hline S.Ed. (+) & 0.092 & 1.519 & 1.041 & 0.082 & 1.641 & 0.412 & 0.371 \\
\hline C.D. at $0.5 \%$ & 0.191 & 3.135 & 2.149 & 0.169 & 3.387 & 0.851 & 0.765 \\
\hline F-Test & $\mathbf{S}$ & $\mathbf{S}$ & $\mathbf{S}$ & $\mathbf{S}$ & $\mathbf{S}$ & S & S \\
\hline CV & 1.003 & 4.129 & 10.043 & 5.495 & 6.049 & 11.955 & 10.987 \\
\hline
\end{tabular}


The lowest observation was recorded in control $T_{0}$ and $T_{1}$ in plants. Total soluble solids (TSS) and Vitamin , „C $\mathrm{C}^{\text {ee }}$ increased progressively with the $50 \% \mathrm{NPK}+50 \%$ vermicompost+Poultry manure because bitter gourd responded favourably and this enhanced the antioxidant (vitamin C) content of the leaves and fruit. Vermicompost released nutrient in soil and provided favorable condition in the plant root zone resulting higher absorption or uptake of major as well as minor nutrient which might have directly related to concentration of T.S.S. in fruits.while vitamin $\mathrm{C}$ were significantly affected with the application of both organic and inorganic fertilizer in different combination.

It is concluded from the experiment that the treatment $\mathrm{T} 1250 \% \mathrm{RDF}$ of $\mathrm{NPK}+50 \%$ Vermicompost + Poultry manure was found suitable for application in Rainy (kharfi) season bitter gourd cultivation for better growth, yield and quality traits and Benefit cost ratio. In terms of cost benefits ratio maximum gross retruns and net retrun was recorded in tretments (T12)50\% RDF of NPK $+50 \%$ Vermicompost+Poultrymanure and cost benefit ratio was found in treament where as minimum Gross return and net return was recorded in Control Recommanded dose of NPK120:60:60 kg/ha + FYM 20t/ha (T0)

\section{References}

Anjanappa M, Venkatesh J, Suresh Kumara B. Influence of organic, inorganic and biofertilizers on flowering, yield and yield attributes of cucumber (cv. Hassan Local) in open field condition. Karnataka Journal. Agric. Sci. 2012; 25(4): 493-497

Anuja, S., and Poovizhi, K. 2009. Effect of organic nutrient son yield and yield attributes of cucumber (Cucumis sativus) cv. Long green, Vegetable
Science6 (2): 163-166

Arfan-ul-Haq M, Ahmad N, Farooq U, Zafar $\mathrm{H}$ and Abd-Ali M (2015). Effect of different organic materials and chemical fertilizer on yield and quality of bitter gourd (Momordica charantia L.).

Behera T.K., Sureja, A. K., Sabina, Islam, Munshi, A. D., and Sidhu, A. S.. Kameswari, M., Lalitha, P., Narayanamma, S., Riazuddin, A., and Charturvedi, A. (2011). Influence of integrated nutrient management in ridge gourd [Luffa acutangula (Roxb.) L.]. Vegetable Science, 38(2): 209-211

Ludwick A E, and Johnstone A M 2002. Organic nutrients. Better Crops, 86: 810

Minor cucurbits. Genetics, genomics and breeding of cucurbits, Pp. 17- 60.

Mulani TG, Musmade AM, Kadu PP and Mangave KK 2007. Effect of organic manures and biofertilizers on growth, yield and quality of bitter gourd (Momordica charantia L) cv Phule Green Gold. Journal of Soils and Crops, 17(2): 258-261.

Prabhu M, Natarajan S, Srinivasan K, Pugalendhi L. Integrated nutrient management in cucumber. Indian Journal of Agricultural Research. 2006; 40(2):123-126.

Prasad PH, Mandal AR, Sarkar A, Thapa U, Maity TK. Effect of biofertilizers and nitrogen on growth and yield attributes of bitter gourd (Momordica charantia L). Proceedings. International Conference on Horticulture, 2009, 738-739.

Sangeeta Shree, Champa Lal Regar, Fiza Ahmad, Vijay Kumar Singh, Ritu Kumari and Amrita Kumari (2018). Effect of organic and inorganic fertilizers on growth, yield and quality attributes of hybrid bittegourd (Momordica charantia L.). Int. 
J.Curr.Microbiol.App.Sci (2018)7(4): 2256-2266

Sreenivas, C., Muralidhar, S. and Rao, M. S. 2000. Yield and quality of ridge gourd fruits as influenced by different levels of inorganic fertilizers \& vermicompost. Annals of Agricultural Research, 21 (2): 262-266.
Thriveni V, Mishra HN, Pattanayak SK, Sahoo GS and Thomson T. (2015). Effect of inorganic, organic fertilizers and biofertilizers on growth, flowering, yield and quality attributes of bitter gourd (Momordica charantia L.). International Journal of Farm Science, 5(1): 24-29.

\section{How to cite this article:}

Prashanthi, Ch., Deepanshu and Reshma. 2021. Effect of Organic Manure and in-organic Fertilizer on Growth, Yield and Quality of Bitter Gourd [Momordica charantia L.]. Int.J.Curr.Microbiol.App.Sci. 10(02): 1690-1696.

doi: https://doi.org/10.20546/ijcmas.2021.1002.200 